\title{
Effect of coral cell on beach deformation by 3-D hydraulic model experiment
}

\author{
[Sang Kil Park ${ }^{1}$, Hong Bum Park ${ }^{1}$, Kyeong Mo Lim ${ }^{1}$, Kwang Soo Lee ${ }^{2}$ ]
}

\begin{abstract}
Recently, coastal environmental pollution is getting serious. Among these, beach erosion has great a significant impact. These coastal structures are made to minimize the loss of sand beach. For this reason, submerged breakwater has been indiscriminately constructed that is planned throughout south korea. In order to prevent erosion, some advanced countries have been installed submerged breakwater or breakwater. Despite of its purpose to keep the shoreline of the beach, it has a quite a few problems. In addition, the purpose of utilizing the space of the marine leisure users does not like that because of the disconnection of the sea using sea space. These methods have resulted in a further erosion of the beach. Therefore, in this study, we propose to develop a economical method of artificial coral cell model that can mitigate degree rate of beach erosion and improve coastal environments without installing the submerged breakwater or breakwater for the maintenance. We compared and analyzed the topographic changes of the artificial coral reef method and the these methods through the 3-D hydraulic experiment. As a result of the experiment, we confirmed the superiority of the deformation effect of the coral cell over submerged breakwater, it demonstrated the effectiveness of prevention of loss of sand and improvement of water quality.
\end{abstract}

Keywords: Beach Erosion, Water Quality, Beach Maintenance, Beach Topography, Artificial Coral Cell Model

\section{INTRODUCTION}

Coastal Environment due to climate change is getting worse and worse. Beach erosion is one of the world's worst disasters. In order to prevent this, Some countries had been indiscriminately installed fixed coastal structures as breakwater or submerged breakwater at the coast. In particular, these were installed to prevent disasters in the countries of Southeast Asia to Typhoon invasion. These structures also have the disadvantage that they do not completely prevent erosion. In Korea, a plan to minimize

\footnotetext{
Sang Kil Park ${ }^{1}$ (Ph.D)/ Chair Professor

School of Civil Engineering \& Environmental Engineering

Pusan National University,

South Korea
}

Hong Bum Park ${ }^{1}$ (Ph.D)

Busan National University

South Korea

Kyeong Mo Lim ${ }^{1}$ (Ph.D)

Busan National University

South Korea

Kwang Soo Lee ${ }^{2}$

Han Ocean Co(Ltd.)

South Korea the erosion of shoreline was implemented by conducting artificial nourishment sand on the coast. Topographical variation occurs due to the installation of the structure. According to the three-dimensional hydraulic model test, at the center of the submerged breakwater, the deposition occurs, in contrast, both ends erode. This phenomenon causes the shoreline to be cusped, which not only provides inconvenience to the visitors, but also generates strong rip current and causes safety accidents. Since access is prohibited to small boats and surfing users, it is inadequate for marine recreational facilities. We want to prevent the erosion of the designated Gwangan beaches at Busan City South Korea and utilize the sea level space as a space for marine leisure.

In short speaking, we are trying to prevent erosion by installing Coral cells on the erosion coasts. To investigate the topographical change of the model beach shoreline, the following three-dimensional experiment was carried out. Firstly, we compared the topographical variations of installing coral cell and not installing coral cell.

Secondly, we compared the topographic variations of submerged breakwater and coral cell installations. These method is to capture the nourishment sand with the Coral cells pockets and retain the nourishment sand in the pockets. The field installation method is to install Coral cells of a certain size on a wide and long underwater sea bottom. 3dimension hydraulic experiments were carried out to investigate the effects of wave damping and prevention of sand outflow. Coral cells weakened the rip current and reduced the loss of nourishment sand. We directly measured the movement of the sand and topographical change by continuous wave action for 20 hours. Nourishment sands flowed out to the deep water until 12 hours, but after 12 hours the sea bottom topography was very stable. That is to say, after 8 hours, there was very little sand movement, and there was almost no variation of contour topographical change. We defined the residual rate of nourishment sand as the amount of nourishment sand remaining in a certain space divided by the total amount of sand. Therefore, the purpose of this study is to propose a Coral cell method to prevent beach erosion without installing a submerged breakwater or breakwater for maintenance of the beach.

\section{THREE DIMENSION HYDRAULIC EXPERIMENT MODEL TEST}

\section{A. Fixed Bed Hydraulic Experiment}


In order to carry out the three dimension hydraulic model experiment, we used the regular. Prior to the experiment of the three dimensional hydraulic model, we carried out a one dimensional hydraulic model experiment. One dimensional hydraulic model experiment was carried out with regular and irregular wave generation tank in the coastal laboratory of the Civil Engineering Department at Pusan National University. Fig. 1 is simple illustration of a water wave tank and a wave device. The specification of the wave tank is shown in Fig. 1, the length is $25 \mathrm{~m}$, height is $1.0 \mathrm{~m}$, width is $11 \mathrm{~m}$.

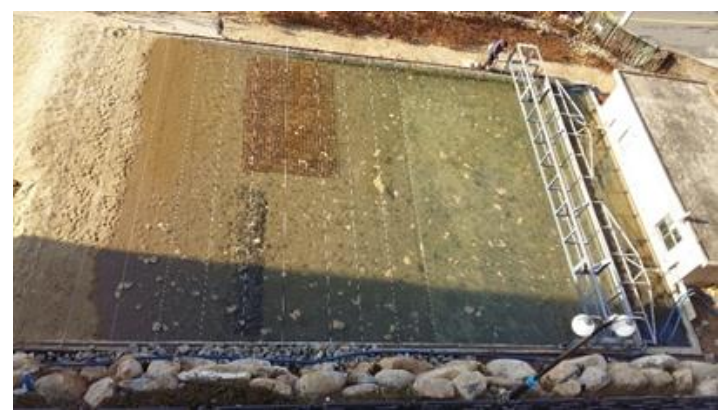

Figure 1. Three dimension hydraulic experiment wave tank

Fig. 2 is model beach of installing with the Coral cell or without Coral cell. In the three dimensional hydraulic model experiment, the regular wave height value used in the one dimensional experiment was used. The wave height was measured at the required point to confirm the same value of the wave height of one dimension model test. The exact measurement point of the incident wave is the measurement desk center of Fig. 1 and the depth is $0.8 \mathrm{~m}$. In order to check the topographic variation of model beach, we used the gauge of sand slope and level instrument of surveying equipment transit. we recorded the values of topographic variation at slope behind the Coral cell and submarined breakwater. The size of the Coral cell used in the movable bed hydraulic experiments (the size of the lower sand capture and the upper wave damp device of the Coral cell) is $10 \mathrm{~cm}$ pocket cell and $10 \mathrm{~cm}$ ripple cell that forms complex structure. The shape of the Coral cell is circular type with a height of length $20 \mathrm{~cm}$ and a diameter $10 \mathrm{~cm}$. Fig. 3 were showed scale of coral cell sketch.

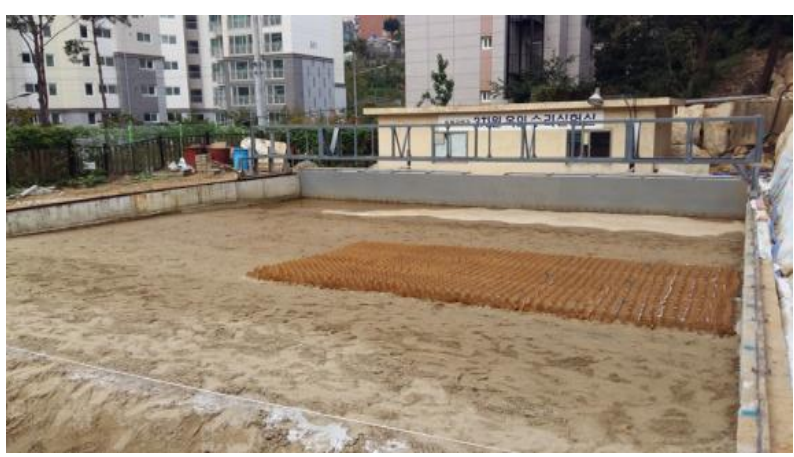

Figure 2. Model beach of installing with the Coral cell or without Coral cell

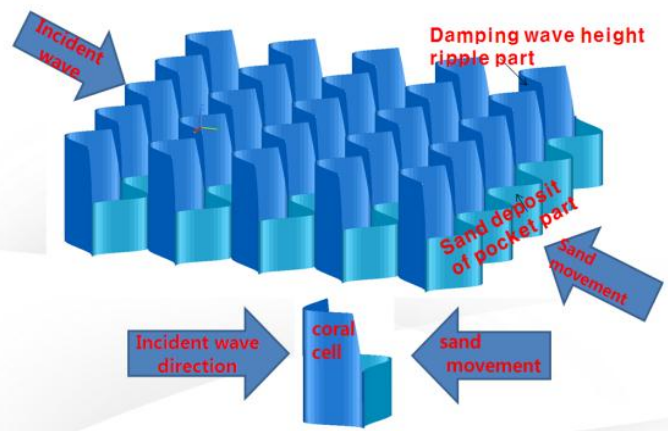

Figure 3.The sketch of Coral cell

\section{B. Beach model bottom and sand deposit coral cell by Experiment}

Sea bottom slope without Coral cell was constructed by setting natural beaches with $1 / 10$ slope. The subsea bottom slope with Coral cell was produced as an 1/10 erosion type of artificial subsea bottom slope. The bottom slope was made of field of model beach grain size sand and the depth of the sandy beaches was made from $40 \mathrm{~cm}$ to $60 \mathrm{~cm}$ deep. Of course, $11 \mathrm{~m}$ water tank was separated by with coral cell and without coral cell. The natural erosion coast was made on the left side wave direction, and Coral cell was installed at the right side of wave direction. The sea bottom slope of model beach is $1 / 10^{\sim} 1 / 30$, Both beaches were constructed to allow erosion of the shoreline by incident waves action. Fig. 4 is the photo which was installed with coral cell group or not. Fig. 4 shows the model beach for a hydraulic model experiment. The sand is deposited within the coral cell. It is the sand that flows from the shoreline of model beach to the deep sea in the hydraulic experiment. Before the 3D model test, we carried out a one dimensional model test for beach model. We will briefly want to explain the irregular wave used in the one dimension experiment. We decided to use the period and the wave height value for the significant wave of the irregular wave in three dimensions.

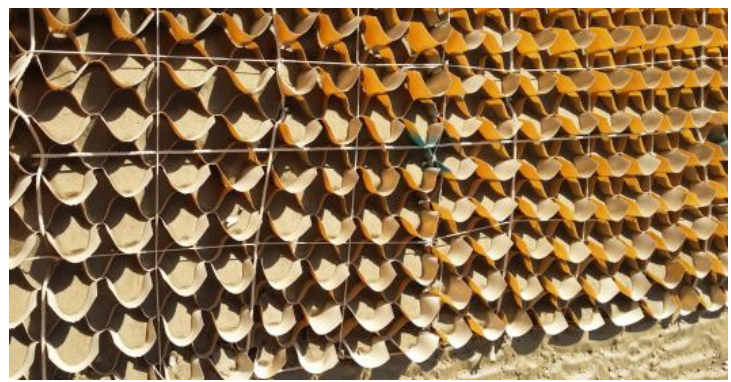

Figure 4. View of sand deposit inside coral cell and settlement of Coral cell 
The time series of irregular wave used in the mobile bed experiment is as same as the time series analyzed in fixed bed model. The incident wave height is the $14 \mathrm{~cm}$ of significant wave height, the period of wave is $0.98 \mathrm{sec}$ of significant waves period, and the wave steepness is 0.093 . In mobile bed 1-D experiments, we examined the topography of beaches elapsed time by using irregular waves. In order to verify the occurrence of the sand bars of beach, Nayak was used as an evaluation criterion of erosion and deposit.[1] Iwatani and Noda 's sand bar occurrence limit formula was used as an evaluation criterion for sandy beaches, and this coastal sandy beach belongs to Johnson' s storm beach.[2][3] The purpose of the mobile bed 1-D experiment is to change the erosion beach to deposit beach. In other words, the nourishment sand did not flow into the deep sea by Coral cell but was collected in the pocket of Coral cell. In this one dimension experiment, we can see that the erosion of model beach changes to a stable condition. This phenomenon is thought to be the result of wave height attenuation by Coral cells in the fixed bed experiment. Experimental progress of the mobile bed 3-D experiment is to verify the variation of topography according to elapsed time. In the mobile bed 3-D experiment, we focused on the variation of topography of sea bottom rather than the trend of the wave distribution. In the first case, the focus of Cases 1 is to compare and analyze the topographic variability for Coral cell installation and without installation. In the second case, the focus of Case 2 is to analyze the topography variation of the coral cell and submerged breakwater. we want to compare the topographic changes of model beach with erosive natural beach, installation of coral cell and submerged breakwater. The 3-D experimental purpose of model beach was to perform a hydraulic experiment to test the pocket function of Coral cell. In these case, the topographic variation is summarized as a photograph, and the capture function of the topographic variation for the Coral cell is confirmed in the hydraulic experiment. Bottom topography of variation elapsed time was measured at intervals of 4 hours. We tried to verify the two functions of the Coral cell, the capture rate and the sea bottom profile rate. Table 1 summarizes the conditions of the mobile bed hydraulic experiment.

\begin{tabular}{clll}
\hline Case & Type of Model Beach & \multicolumn{1}{c}{$\begin{array}{c}\text { Measuring } \\
\text { Time }\end{array}$} & Observation \\
\hline Case1 & $\begin{array}{l}\text { Natural Beach+ Coral } \\
\text { Cell Beach }\end{array}$ & $\begin{array}{l}\text { Every 2 hours } \\
\text { total 24 hours }\end{array}$ & $\begin{array}{l}\text { H.W.L. } \\
\text { Height } \\
\text { sand }\end{array}$ \\
\hline Case2 & $\begin{array}{l}\text { Coral Cell Beach }+ \\
\text { submerged breakwater } \\
\text { Beach }\end{array}$ & $\begin{array}{l}\text { Every 2 hours } \\
\text { (total 24 hours } \\
\text { passed) }\end{array}$ & \\
& &
\end{tabular}

TABLE I . Condition of mobile bed 3-D experiment

\subsection{Model of Topographic Bed of Coral cell Installation and Submerged Breakwater}

As mentioned above, table 1 shows the conditions of the mobile bed hydraulic 3-D experiment, and Case 1 and Case 2 have clearly same purpose for the mobile bed hydraulic experiment. We decided to measure the topography variation and the nourishment sand of capture rate according to the elapsed time of hydraulic experiment. The purpose of estimating the capture rate is that nourishment sand does not flow into the deep sea by Coral cell but remains in the pocket to maintain stable beach of topography. Generally, the wave height is not measured in a 3-dimensional mobile bed hydraulic model test. The geometric scale ratio was $1 / 10$. Scale $1 / 10$ is widely used for hydraulic model tests to show the reproducibility of the wave and sea bottom of topography variation. Fig. 5 shows a submerged breakwater and with Coral cell type installed on an eroded beach to prevent erosion. Fig. 4 is figure of the Coral cell with a nourishment sand capture and a wave attenuator. In this figure, the direction of the arrow indicates the direction of incident wave and the main direction of nourishment sand out flow. To be honest, the larger the Coral cell of the pocket and ripple, the greater the wave reduction and the nourishment sand of capture rate. Beach erosion due to climate change is one of the world's worst disasters. In order to prevent this, we are indiscriminately installing submerged breakwater, ignoring use and environment of the coast. In Korea, a plan to minimize the erosion of shoreline was implemented by conducting artificial nourishment on the Gwanganri beach of Busan City Southwest of Korea. At the center of the submerged breakwater, the deposition occurs, in contrast, both ends erode. This phenomenon causes the shoreline to be cusped, which not only provides inconvenience to the visitors, but also generates strong rip current and causes safety accidents.

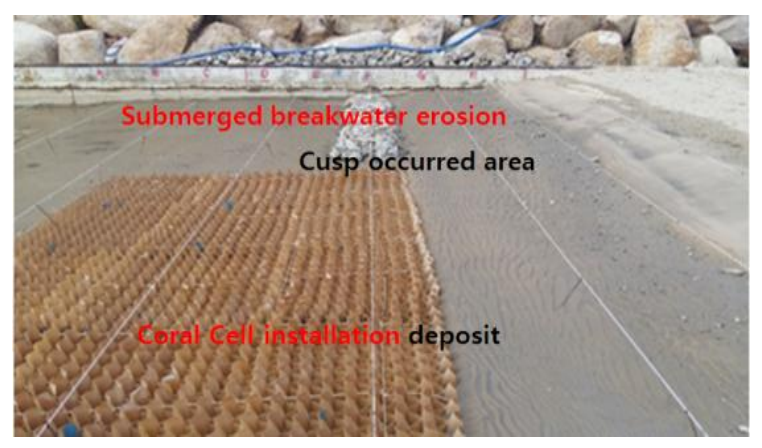

Figure 5. Photo view of submerged breakwater and coral cell of installation

\section{EXPERIMENT ANALYSIS}

\section{A. Situation of Sand Movement by Coral cell Installation}

The mobile bed experiments were carried out to understand the movement of the nourishment sand in accordance with the elapsed time of the wave action. As you can see fig. 4, we could confirm the movement of the nourishment sand along with the elapsed time of wave after installing the Coral cell. In other words, we can see that nourishment sand is flowing into the Coral cell pocket and deposited. Fig. 4 shows the state in which the Coral cell is 
buried by the movement of the sand. This phenomenon shows that the nourishment sand flows into the pocket of Coral cell and accumulates as the shoreline erode. The red line is the topography of original sea bottom. We checked the amount of the sand is deposited in one of the pocket obtained in the experiment. Table 2 was showed the volume of deposit sand and percent due to elapsed time of the wave action. We found that the deposit rate increased up to 12 hours, but not after 12 hours. Table 2 shows the maximum value at $59 \%$ after 18 hours of elapsed time.

TABLE II. VOLUME OF SAND DEPOSIT ONE POCKET CORAL CELL BY ELAPSED TIME

\begin{tabular}{|c|c|c|c|c|c|c|}
\hline $\begin{array}{c}\text { time } \\
(\mathbf{h r} .)\end{array}$ & 4 & 8 & 12 & 16 & 20 & 24 \\
\hline $\begin{array}{c}\text { Vol. } \\
\left(\mathbf{c m}^{\mathbf{3}}\right)\end{array}$ & 149.2 & 282.6 & 400.4 & 421.2 & 411.6 & 422.3 \\
\hline $\begin{array}{c}\text { rate } \\
(\%)\end{array}$ & 19 & 36 & 51 & 054 & 053 & 054 \\
\hline
\end{tabular}

\section{B. Change of Sea Bottom Topography by Coral cell}

Fig. 6 shows the sea bottom contour topography of variation according to elapsed time of wave action. The thin black lines are subsea fixed slope, the red line is the sand depth of the initial sea bottom topography. The dark blue is the deep depth, nourishment sand is not move. The light blue zone was showed the moving nourishment sand area. The yellow part is the area where the nourishment sand moves heavily. The red part is a beach without sand movement. In this Fig.6, we can see three phenomena. Firstly, the installation of Coral cell can protect the area erosion more than a certain value. Secondly, the nourishment sand on the steep slope can be collected in Coral cell to increase the rate of deposition, the sand that flows into the deep sea area flows into the pocket of Coral cell again and is deposited from the deep water depth of the Coral cell. Thirdly, the nourishment sand that flows out into the deep water area flows back into the Coral cell and change from steep slope to mild slope.

Fig. 6 is contour of topographic variation according with coral cell or not for elapsed time of wave (24hr.)

\section{Sand Volume and Deposit Rate by Installation of Coral cell and Submerged Breakwater}

Table 3 shows the amount of sand where a submerged breakwater and a coral cell are installed at model beach. We could confirm in table 3 that nourishment sand was being deposited in the pocket of coral cell. As shown in table 2, the deposition rate increases with the elapsed of time, but the increase is very small after 16 hours. The volume of one pocket cell was calculated assuming a cylinder with a height of $10 \mathrm{~cm}$ and a diameter of $10 \mathrm{~cm}$. Therefore, the total amount of sand deposited in one pocket cell is $785 \mathrm{~cm}^{3}$. The accumulation rate means the average value of the whole pocket cell.

This means that about $50 \%$ of the sand flowing into the deep sea can be prevented from flowing out. However, we can see that the erosion is continuing progressing due to the severe scouring around the submerged breakwater. This phenomenon is occurring more severely with increasing elapsed time.

TABLE III. VOLUME OF SAND DEPOSIT ONE POCKET CORAL CELL A SUBMERGED BREAKWATER AND A CORAL CELL INSTALLATION.

\begin{tabular}{|c|c|c|c|c|c|c|}
\hline $\begin{array}{c}\text { time } \\
\text { (hr.) }\end{array}$ & 4 & 8 & 12 & 16 & 20 & 24 \\
\hline $\begin{array}{c}\text { Vol. } \\
\left(\mathbf{c m}^{3}\right)\end{array}$ & 125.6 & 266.9 & 345.4 & 384.7 & 400.5 & 408.2 \\
\hline $\begin{array}{c}\text { rate } \\
(\%)\end{array}$ & 16 & 34 & 44 & 49 & 51 & 52 \\
\hline
\end{tabular}

\section{Topographic changes due to simultaneous installation of submerged and coral cell}

Fig. 7 shows the topographic changes in contour lines when the submerged breakwater and the coral cell are installed at the same time. By installing coral cell and submerged breakwater, most of nourishment sand is caught in Coral cell pocket. Fig. 7 also shows the same topographic variation, as shown in Fig. 6. You can see Fig. 7, severe erosion occurred in the back area of the submerged breakwater, but little deposit occurred due to increasing elapsed time. However, at the back area of the coral cell, the deposition of sand presented clearly due to elapsed time. Therefore Coral cell behind area the sand deposition occurs, and behind the submerged breakwater is very likely to cause erosion. We found that installing the Coral cells can reliably capture the nourishment sand that flows into the deep water.

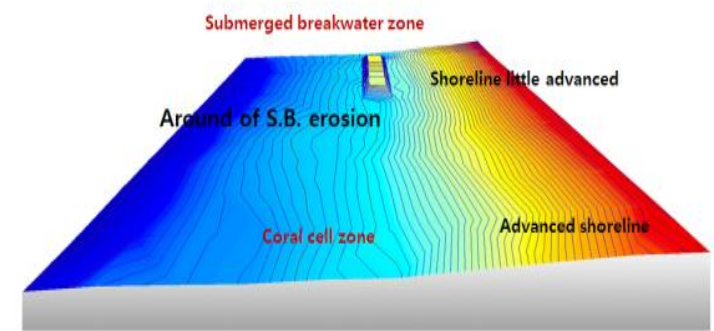

Figure. 6. The topographic changes of cont0ur with coral cell or not 
Figure 6 and Figure 7 show the topographic variation of the model beach after 24 hours of wave action, We can see erosion occurred without coral cell, Coral cell was installed, deposit occurred.

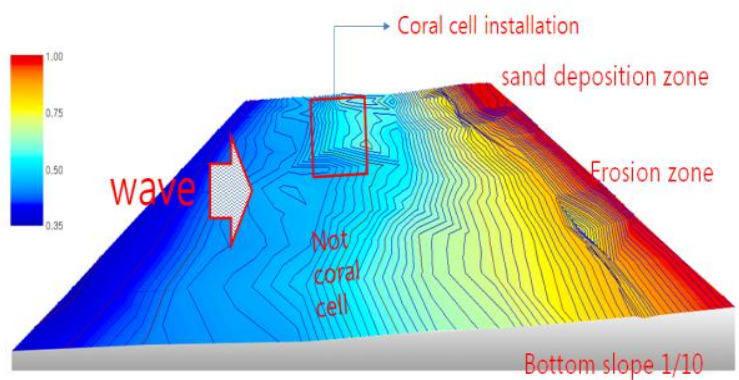

Figure. 7 The topographic changes of contour lines with submerged breakwater and the coral cell

\section{E. Current Analysis at Model Beach}

Fig. 8 showed current at model Beach of Gwanganri Busan South Korea. Most of the near shore current at the model beach is classified into rip current and longshore current. In the central part of the model beach, rip current is strong, and longshore current is strong at both side part of model beach. Therefore, the sand moves to the deep sea in the central part, and the sand does not flow to the deep sea in both parts, and sand deposition occurs here. Since the sand moves along the nearshore current at surf zone in coast, it is necessary to control the nearshore current to control the movement of the sand.

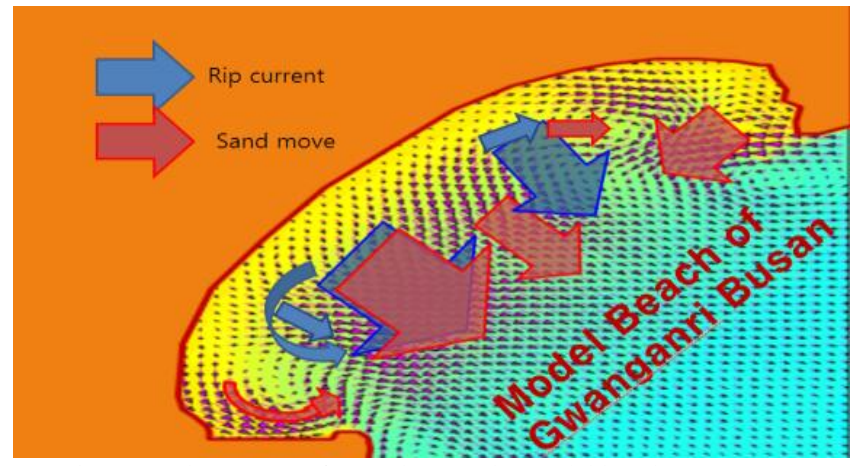

Figure 8 . The current of near shore at the model beach.
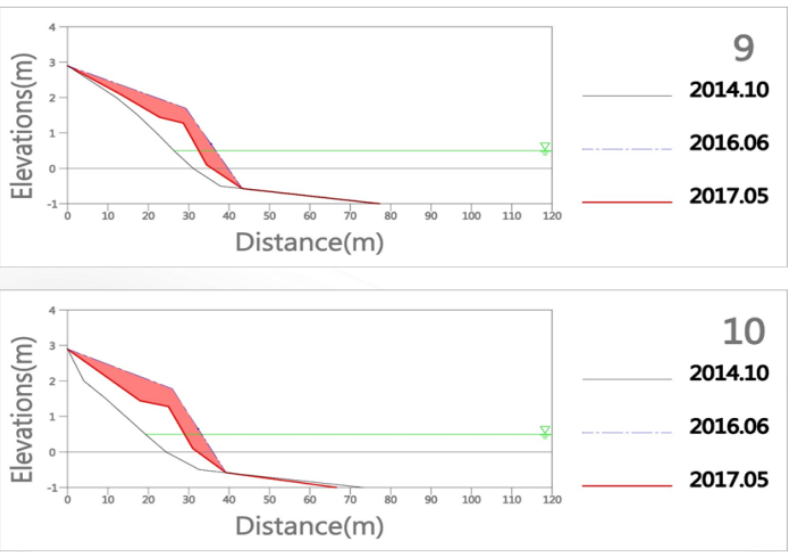

Figure 9. Changes section of beach by typhoon

We surveyed the Gwanganri beach for four years. Figure 9 shows a longitudinal section of a beach. No. 9 and 10 are the central points of Fig. 8 where strong erosion occurs. We will verify the applicability by installing the coral cell method at these points.

\section{CONCLUSION}

It is a very difficult task to stabilize the beach by conducting nourishment sand on the erosive natural beach. The purpose of this study is to investigate the maintenance strategies to enlarge availability for artificial nourishment sand in Gwanganri beach in Busan, South Korea. In other words, this research proposed an erosion prevention method using Coral cell as a customized method. As a results of the three dimensional hydraulic experimental model, this method was able to prevent model beach erosion from typhoon as over $50 \%$.

\section{ACKNOWLEDGEMENT}

This research was supported by research fund of P.N.U. Small Business Incubator Center, Han Ocean Co. Ltd and Green Land \& Water Management Research Institute.

\section{REFFERENCE}

[1] Nayak IV, "Equilibrium profiles of model beaches", Proc. $12^{\text {th }}$ Int. Conf. on Coastal Eng.,1971pp.1321-1339.

[2] Noda H, "Initial movement of sea bottom sand inception and generation sand ripples due to waves", Proc. $11^{\text {th }}$ Conf. on Coastal Eng. in Japan,1964,pp. 135-141.

[3] Iwagaki Y, "Laboratory study of scale effects in two dimensional beach process", Proc. $8^{\text {th }}$ Int. Conf. on Coastal Eng., 1963,pp.194-210.

[4] S.K. Park, H.B. Park, K.M. Lim" The Study on Mitigation Method of Beach Erosion using Coral cell" Proc. $3^{\text {th }}$ international conference on Science \& engineering, USQ Brisbane Australia. Nov. 13-16, 2017, pp467-472

About Author

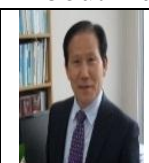

Prof.(Ph.D) of S. K. Park has been working for 30yr. at Dept. of Civil Engineering, Pusan National University South Korea. He has studied a variety of hydraulic dynamics subjects: however, his research interests include numerical modeling of wave's action behavior, nonlinear wave theory dynamics analysis, environmental change of beach shoreline, beach deformation of hydraulic model experiment test, design of new port system, and prevention of disaster of typhoon. He is also author or co-author of some publications 